\title{
Impacts of climatic changes on the vegetative development of olive cultivars
}

\author{
Gabriel W. L. Florêncio ${ }^{1}$, Fabrina B. Martins ${ }^{1}$, Mábele de C. Ferreira ${ }^{1}$ \& Rodolfo A. de A. Pereira ${ }^{2}$ \\ ${ }^{1}$ Universidade Federal de Itajubá/Natural Resources Institute. Itajubá, MG, Brasil. E-mail: gabrielflorencio1797@gmail.com - ORCID: 0000-0003-3510- \\ 884X; fabrinabm@gmail.com (Corresponding author) - ORCID: 0000-0003-0401-6168; mabeleferreira@yahoo.com.br - ORCID: 0000-0001-6724-7217 \\ ${ }^{2}$ Universidade de São Paulo/Escola Superior de Agricultura Luiz de Queiroz. Piracicaba, SP, Brasil. E-mail: rodolfopereira@usp.br - ORCID: 0000-0002- \\ $3240-4611$
}

\begin{abstract}
The aim of this study was to simulate the vegetative development of the olive cultivars

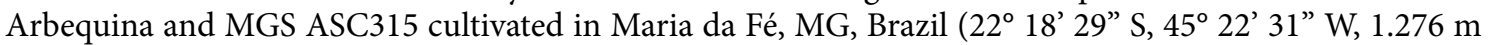
of altitude). The development of these cultivars was simulated in nine transplanting dates, considering three distinct scenarios for three periods (2011-2040, 2041-2070 and 2071-2100). Climate changes influence the olive crop management. The increase in air temperature modifies the development rate and the duration of the seedling phase of the cultivars Arbequina and MGSASC315. In colder months, there is accelerated vegetative development and shorter seedling phase duration. Conversely, in warmer months, there is delayed development with longer seedling phase duration.
\end{abstract}

Key words: Olea europaea L., phenology, air temperature

\section{Impactos de mudanças climáticas no desenvolvimento vegetativo de cultivares de oliveira}

RESUMO: Este estudo teve como objetivo simular o desenvolvimento vegetativo das cultivares de oliveira Arbequina e MGS ASC315 cultivadas em Maria da Fé, MG, Brasil (22 18’ 29” S, $45^{\circ} 22^{\prime} 31^{\prime \prime}$ W, $1.276 \mathrm{~m}$ de altitude). O desenvolvimento destas cultivares foi simulado em nove épocas de transplantio, considerando três cenários distintos para três períodos (2011-2040, 2041-2070 e 2071-2100). As mudanças climáticas influenciaram o manejo da cultura da oliveira. $\mathrm{O}$ aumento na temperatura modifica a taxa de desenvolvimento e a duração da fase de muda das cultivares de oliveira Arbequina e MGS ASC315. Em meses mais frios, existe o desenvolvimento vegetativo acelerado e redução da duração da fase de muda, enquanto em meses mais quentes, existe um desenvolvimento retardado com aumento da duração da fase de muda.

Palavras-chave: Olea europaea L., fenologia, temperatura do ar 


\section{INTRODUCTION}

The Intergovernmental Panel on Climate Change (IPCC, 2013) has projected increases in atmospheric $\mathrm{CO}_{2}$ and air temperature up to $5.0^{\circ} \mathrm{C}$ in the state of Minas Gerais, Brazil, in the $21^{\text {st }}$ century (Santos et al., 2017b). In theory, C3 plants, which represent most terrestrial species, should be favored by the increase of $\mathrm{CO}_{2}$ since they are highly dependent on atmospheric $\mathrm{CO}_{2}$ to have the enzyme Rubisco, which is solely responsible for the metabolic process that governs photosynthesis in C3 plants (Fagundes et al., 2010; Taiz et al., 2018). Conversely, the Warburg effect occurs under high temperature conditions, in which $\mathrm{O}_{2}$ inhibits the fixation of $\mathrm{CO}_{2}$ by the Rubisco enzyme, thus reducing photosynthesis and increasing photorespiration (Marenco \& Lopes, 2009). This impact hinders development because it shortens the cycle duration and reduces yield, due to the reduction of photosynthesis and the accumulation of photoassimilates (Fagundes et al., 2010). Thus, studies examining the potential impacts of climatic changes on the development of annual and perennial species are important in scenarios with promising economic potential (IPCC, 2013; Walter et al., 2014), such as olive trees that are cultivated in the southern and southeastern regions of Brazil (Martins et al., 2012; Wrege et al., 2015; Santos et al., 2017b).

The impact of climate change on olive crops can be analyzed through the development of simulation models which are commonly used for annual crops (Streck et al., 2011) and scarce for perennial crops (Costa \& Streck, 2018). These models simulate the development through leaf appearance rate (LAR), using air temperature response functions, differing basically between linear or additive and non-linear or multiplicative categories (Martins et al., 2014). The aim of the present study was to simulate the vegetative development of the cultivars Arbequina and MGS ASC315 in nine transplanting dates, considering different climate projections.

\section{Material And Methods}

Due to the expansion of olive crops cultivation in Minas Gerais, Brazil (Garcia et al., 2018), a numerical study was performed in Maria da Fé, MG, Brazil ( $22^{\circ} 18^{\prime} 29^{\prime \prime} \mathrm{S}, 45^{\circ} 22^{\prime} 31^{\prime \prime} \mathrm{W}, 1.276 \mathrm{~m}$ of altitude). According to Köppen classification, the region presents Cwb climate, characterized by dry winters and rainy summers (Souza \& Martins, 2014). The cultivars Arbequina and MGS ASC315 were chosen because both have been used with the objective of producing olive oil in the region (Martins et al., 2012).

The vegetative development models (VD) used in this study were differentiated for each cultivar, with the Wang and Engel model (WE) for Arbequina and the Phyllochron model (PHYL) for MGS ASC315, based on the results obtained by Martins et al. (2014). In both models, VD is given by the number of accumulated leaves in the main stem (NL) which integrated in time provides the duration of the seedling phase (DSS), which refers to the number of days between the transplanting date and the threshold of $\mathrm{NL}=20$ (Martins et al., 2012, 2014).

In the WE model, NL is given by Martins et al. (2014) Eq. 1:

$$
\mathrm{NL}_{\text {estimated }}=\sum_{\mathrm{i}=1}^{\mathrm{n}}\left(\mathrm{LAR}_{\text {max }} \mathrm{f}(\mathrm{T})\right)
$$

where:

$\mathrm{NL}_{\text {estimated }}$ - number of accumulated leaves in the main stem;

$\mathrm{LAR}_{\max }$ - maximum daily leaf appearance rate $(0.270390$ leaves $\left.\mathrm{d}^{-1}\right)$; and,

$f(T)$ - beta function of air temperature (Eqs. 2 and 3):

$f(T)=\frac{\left[2(T m-T b)^{\alpha}(T o t-T b)^{\alpha}-(T m-T b)^{2 \alpha}\right]}{(T o t-T b)^{2 \alpha}}$, when $T b \leq T m \leq T B$

$$
\mathrm{f}(\mathrm{T})=0 \text {, when } \mathrm{Tm}<\mathrm{Tb} \text { or } \mathrm{Tm}>\mathrm{TB}
$$

where:

Tm - daily mean air temperature;

$\mathrm{Tb}$, Tot and $\mathrm{TB}$ - cardinal temperatures for Arberquina (10.5, 16.1 and $37.8^{\circ} \mathrm{C}$, respectively) (Lisboa et al., 2012; Martins et al., 2012, 2014); and,

a - calibration coefficient (Eq. 4):

$$
\alpha=\frac{\ln 2}{\ln [(\mathrm{TB}-\mathrm{Tb}) /(\mathrm{Tot}-\mathrm{Tb})]}
$$

where:

i - date of the beginning of simulation (Table 1); and,

$\mathrm{n}$ - date that the cultivar Arbequina reaches NL $=20$.

In the PHYL model, NL is given by Martins et al. (2014) (Eq. 5):

$$
\mathrm{NL}_{\text {estimated }}=\mathrm{STac}_{\mathrm{i}=1}^{\mathrm{n}} / \overline{\mathrm{PHYL}}
$$

where:

STac - air temperature function, given by the sum of the daily thermal time (Std) (Eqs. 6 to 8):

$$
\mathrm{Std}=(\mathrm{Tm}-\mathrm{Tb}) 1 \text { day, when } \mathrm{Tb}<\mathrm{Tm} \leq \mathrm{Tot}
$$

$\mathrm{Std}=(\mathrm{Tot}-\mathrm{Tb})\left[\frac{\mathrm{Tm}-\mathrm{TB}}{\mathrm{Tot}-\mathrm{Tb}}\right] 1$ day, when $\mathrm{Tot}<\mathrm{Tm} \leq \mathrm{TB}$

$$
\text { Std }=0 \text {, when } \mathrm{Tm} \leq \mathrm{Tb} \text { or } \mathrm{Tm} \geq \mathrm{TB}
$$

where:

$\mathrm{Tb}$, Tot and TB - cardinal temperatures for MGSASC315 (11.0, 14.7 and $37.8{ }^{\circ} \mathrm{C}$ respectively) (Lisboa et al., 2012; Martins et al., 2012, 2014);

n - when the cultivar MGSASC315 reaches $\mathrm{NL}=20$; and, $\overline{\mathrm{PHYL}}$ - average phyllochron values $\left(17.05^{\circ} \mathrm{C} \mathrm{d}\right.$ leaf $\left.{ }^{-1}\right)$.

Tm data from three General Circulation Models (GCMs) MIROC5 (M1), IPSL-CM5 (M2) and MRI-CGC (M3) (MCGs) members of the Coupled Models Intercomparison Project Phase 5 (CMIP5) were used in the air temperature functions of the VD models ( $\mathrm{f}(\mathrm{T})$ of the WE and STac models in the PHYL model). GCMs were chosen due to the unavailability of up-to-date results from regional models, which are highly computationally costly. Besides, the new generation of GCMs 
Table 1. Beginning of the simulations based on transplanting date (TT) and duration of the seedling phase, in calendar days, in both olive cultivars

\begin{tabular}{|c|c|c|}
\hline \multirow{2}{*}{$\begin{array}{c}\text { Transplanting } \\
\text { date (i) }\end{array}$} & \multicolumn{2}{|c|}{ Duration of the seedling phase (days) } \\
\hline & Arbequina & MGS ASC315 \\
\hline TT1 - 20/05/2010 & 69 & 84 \\
\hline TT2 - 20/06/2010 & 100 & 170 \\
\hline TT3 - 20/07/2010 & 76 & 132 \\
\hline TT4 - 20/08/2010 & 64 & 126 \\
\hline TT5 - 29/09/2010 & 91 & 110 \\
\hline TT6 - 27/10/2010 & 69 & 110 \\
\hline TT7 - 20/11/2010 & 72 & 100 \\
\hline TT8 - 21/12/2010 & 70 & 98 \\
\hline TT9 - 15/01/2011 & 89 & 108 \\
\hline
\end{tabular}

${ }^{\mathrm{a}}$ Extracted from Martins et al. (2014)

represents the state of the art in climate system modeling (Santos et al., 2017b).

Future climate simulations of CMIP5 use the new generation of radiative forcing scenarios called Representative Concentration Pathways (RCPs) -2.6, 4.5 and 8.5, which correspond to approximate radiative forcing of 2.6, 4.5 and $8.5 \mathrm{~W} \mathrm{~m}^{-2}$, associated with $\mathrm{CO}_{2}$ equivalent concentrations of 490,650 and $1.370 \mathrm{ppm}$, respectively at the end of the $21^{\text {st }}$ century (Moss et al., 2010; Vuuren et al., 2011).

The Tm used in the VD models was obtained by Eq. 9:

$$
\mathrm{Tm}=(\operatorname{Tmax}+\mathrm{Tmin}) / 2
$$

where:

Tmax - obtained by the average daily maximum air temperatures of the three GCMs $\left({ }^{\circ} \mathrm{C}\right)$; and,

Tmin - obtained by the average daily minimum air temperatures of the three GCMs $\left({ }^{\circ} \mathrm{C}\right)$.

It was necessary to make Tm corrections in the three GCMs. Therefore, the methodology proposed by Lenderink et al. (2007) was used. It is based on the monthly bias between the climatic means (NP) obtained with the meteorological station data and the climatic means of the historical period of the GCMs, both for 1971 to 2000. Subsequently, the bias was applied to the daily values of Tm for the month in question (January: 3.4; February: 2.8; March: 3.1; April: 3.2; May: 4.7;
June: 4.8; July: 4.5; August: 4.5; September: 3.8; October: 3.5; November: 3.9; December: $\left.3.2\left({ }^{\circ} \mathrm{C}\right)\right)$.

Finally, to evaluate the impact of climate change on the DSS variable, the analysis of variance (ANOVA) was applied in a tri-factorial scheme $(9 \times 3 \times 3)$ to evaluate the effect of the sources of variation: transplanting dates (nine periods), representative concentration pathways (RCPs 2.6, 4.5 and 8.5) and projections $(\mathrm{PR} 1=2011-2040, \mathrm{PR} 2=2041-2070$ and PR3 = 2071-2100), as recommended by Streck et al. (2013). The DSS values were submitted to the Shapiro-Wilk normality test $(\mathrm{p} \leq 0.05)$ and the means were compared by the Scott-Knott test $(p \leq 0.05)$ using the software SISVAR 5.3 (Ferreira, 2011).

\section{Results AND Discussion}

The air temperature projections for each RCP demonstrate a gradual increase in mean, maximum and minimum air temperatures throughout the $21^{\text {st }}$ century, especially for RCP 8.5. This is expected because it presents the greatest radiative forcing $\left(8.5 \mathrm{~W} \mathrm{~m}^{-2}\right)$ and concentration of emitted $\mathrm{CO}_{2}(1.370 \mathrm{ppm})$ (Riahi et al., 2011) (Figure 1).

This increase can reach $1.5^{\circ} \mathrm{C}$ in the short term (PR1), $3.0^{\circ} \mathrm{C}$ in the medium term (PR2) and up to $4.0^{\circ} \mathrm{C}$ in the long term (PR3) for Maria da Fé, MG, Brazil (Table 2). This corroborates the values recorded by Santos et al. (2017b) for the state of Minas Gerais, Brazil.

Such increases in air temperature (Figure 1) will result in direct damage to the physiological processes of plants, influencing the duration of the vegetative and reproductive stages in olive crops (Tanasijevic et al., 2014) and, consequently, in the DSS. This occurs because the reactions of photosynthesis and photorespiration, enzymatic activities, rate of transport and translocation of solutes (Freitas et al., 2017) are intensified or reduced based on the temperature (Taiz et al., 2018).

Generally, in the current and future climates (PR1, PR2 and PR3), the DSS in Arbequina is lower than in MGS ASC315. In addition, except for TT5 $(i=29 / 09)$ and TT9 $(i=15 / 01)$, there is a similar behavior of DSS between the two cultivars, radiative forcing and projections. The rise in temperature will increase the DSS in TT1 (20/05), TT4 (20/08), TT6 (27/10), TT7 (20/11) and TT8 (21/12) and reduce DSS in TT2 (20/06)

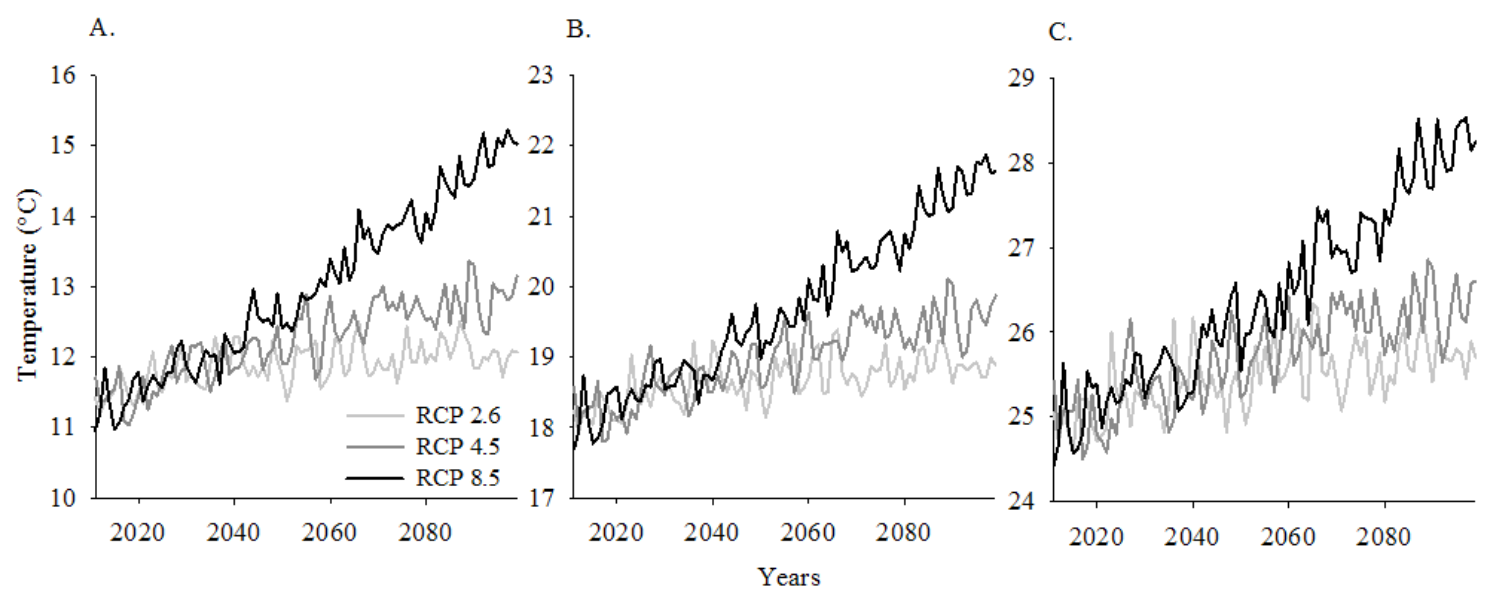

Due to their values, the axes of the air temperature variables have different scales

Figure 1. Minimum (A), mean (B) and maximum (C) temperature projections obtained by the average of three general circulation models (GCMs) for three representative concentration pathways (RCP 2.6, 4.5, 8.5) 
Table 2. Characterization of medium air temperature $\left({ }^{\circ} \mathrm{C}\right)$ for simulations based on transplanting dates (TT) for the cultivars Arbequina and MGSASC315 for short (PR1 = 2011-2040), medium (PR2 = 2041-2070) and long term projections (PR3 = 20712099) in three representative concentration pathways - RCP (2.6, 4.5 and 8.5) for Maria da Fé, MG, Brazil

\begin{tabular}{|c|c|c|c|c|c|c|c|c|c|}
\hline \multirow{2}{*}{$\begin{array}{c}\text { Transplanting } \\
\text { date* }\end{array}$} & \multicolumn{3}{|c|}{ RCP 2.6} & \multicolumn{3}{|c|}{ RCP 4.5} & \multicolumn{3}{|c|}{ RCP 8.5} \\
\hline & PR1 & PR2 & PR3 & PR1 & PR2 & PR3 & PR1 & PR2 & PR3 \\
\hline \multicolumn{10}{|c|}{ Arbequina } \\
\hline TT1 & 13.2 & 13.5 & 13.7 & 13.2 & 13.7 & 14.2 & 13.2 & 14.2 & 15.5 \\
\hline TT2 & 14.2 & 14.4 & 14.6 & 14.0 & 14.5 & 14.9 & 14.1 & 15.2 & 16.6 \\
\hline TT3 & 16.4 & 16.5 & 16.6 & 16.2 & 16.6 & 17.2 & 16.2 & 17.8 & 19.5 \\
\hline TT4 & 19.1 & 19.2 & 19.4 & 18.8 & 19.5 & 20.0 & 18.9 & 20.6 & 22.2 \\
\hline TT5 & 21.0 & 21.3 & 21.4 & 20.8 & 21.7 & 22.1 & 21.1 & 22.5 & 23.9 \\
\hline TT6 & 21.7 & 22.0 & 22.1 & 21.4 & 22.2 & 22.6 & 21.7 & 22.9 & 24.4 \\
\hline TT7 & 22.0 & 22.3 & 22.4 & 22.0 & 22.7 & 23.1 & 22.2 & 23.4 & 24.7 \\
\hline TT8 & 22.1 & 22.4 & 22.5 & 22.2 & 22.8 & 23.1 & 22.3 & 23.3 & 24.5 \\
\hline TT9 & 21.6 & 21.9 & 21.9 & 21.7 & 22.2 & 22.6 & 21.7 & 22.6 & 23.7 \\
\hline \multicolumn{10}{|c|}{ MGS ASC315 } \\
\hline TT1 & 14.8 & 14.7 & 14.9 & 14.7 & 14.8 & 15.1 & 14.7 & 15.3 & 16.3 \\
\hline TT2 & 16.3 & 16.3 & 16.3 & 16.1 & 16.4 & 16.7 & 16.2 & 17.2 & 18.1 \\
\hline TT3 & 17.9 & 18.0 & 18.2 & 17.7 & 18.3 & 18.8 & 17.8 & 19.3 & 21.0 \\
\hline TT4 & 19.8 & 20.1 & 20.2 & 19.6 & 20.4 & 20.9 & 19.8 & 21.4 & 23.1 \\
\hline TT5 & 21.4 & 21.8 & 21.9 & 21.3 & 22.2 & 22.6 & 21.6 & 22.9 & 24.2 \\
\hline TT6 & 21.8 & 22.2 & 22.2 & 21.8 & 22.5 & 22.9 & 22.0 & 23.1 & 24.2 \\
\hline TT7 & 21.8 & 22.1 & 22.2 & 21.8 & 22.4 & 22.8 & 22.0 & 22.9 & 24.0 \\
\hline TT8 & 21.3 & 21.6 & 21.6 & 21.3 & 21.9 & 22.2 & 21.4 & 22.2 & 23.1 \\
\hline TT9 & 20.2 & 20.4 & 20.5 & 20.3 & 20.7 & 21.1 & 20.2 & 21.0 & 22.0 \\
\hline
\end{tabular}

* For transplating dates consult Table 1

and TT3 (20/07) in both cultivars. Except for TT1, the increase in DSS occurred in simulations performed in periods with the highest air temperatures (Table 2). On the contrary, the reduction of DSS (about 20 days for Arbequina and 50 for
MGS ASC315) occurred in periods with the lowest values of air temperature, especially in TT3 and in RCP 8.5 (Figure 2).

The increase in DSS occurred mainly in the spring and summer (MGS ASC 315) (TT6, TT7, TT8 and TT9) (Figure 2), in
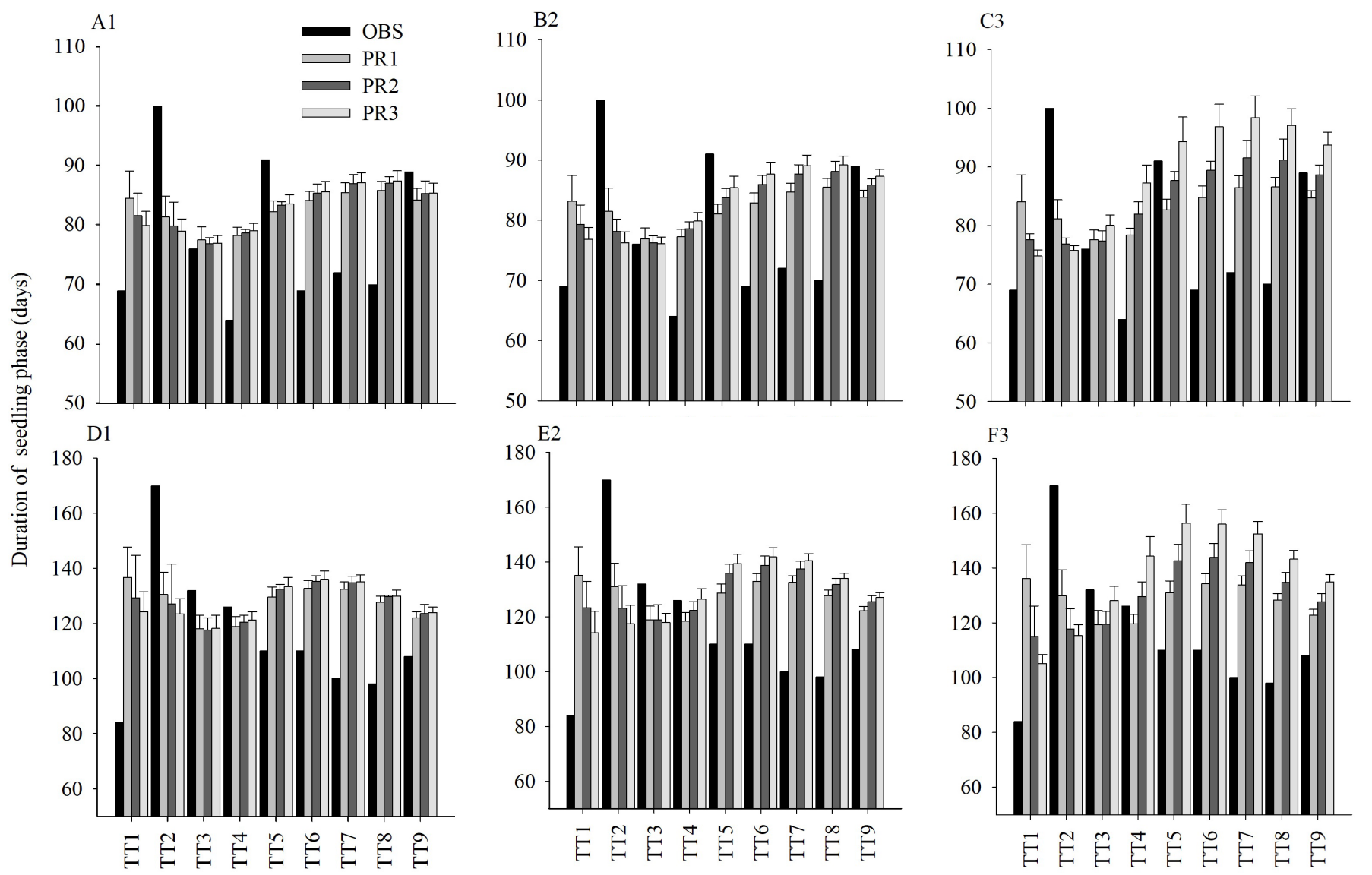

Transplanting dates

For transplating dates consult Table 1 . The vertical lines refer to the standard deviation

Figure 2. Duration of the seedling phase (DSS) for the cultivars Arbequina (A, B and C) and MGSASC315 (D, E and F) observed $($ OBS $)$ and simulated for short $(P R 1=2011-2040)$, medium $(P R 2=2041-2070)$ and long term projection $($ PR3 = 2071-2099) in representative concentration pathways - RCPs 2.6 (1), 4.5 (2) and 8.5 (3) 
which the highest values of Tm were projected; this is similar to what was observed for the VD of red rice (Streck et al., 2013) and potato (Streck et al., 2006). This occurs because at higher temperatures, especially above Tot (Arbequina $=$ $16.1{ }^{\circ} \mathrm{C}$ and MGS ASC315 = $14.7{ }^{\circ} \mathrm{C}$ ) (Lisboa et al., 2012), there is a reduction in the development rate, thus increasing the DSS. Reduced development occurs due to higher breath maintenance rate, energy-consuming process (ATP and $\mathrm{NADPH}$ ) or carbon skeletons from photosynthesis (Taiz et al., 2018), which raise maintenance costs by increasing protein turnover and maintaining ionic balance (Marenco \& Lopes, 2009; Ruelland \& Zachowski, 2010).

Significant effect of triple interaction was verified among transplanting dates, radiative forcing and projections for both cultivars ( $\mathrm{p} \leq 0.05$ ) on the DSS. Among the main effects, the highest values of the f-test were for the transplanting date (1061.51: Arbequina and 506.53: MGSASC315), RCP (420.57: Arbequina and 161.84: MGSASC315) and projection (225.81: Arbequina and 84.67: MGS ASC315). This indicates that the transplanting date has a greater effect on VD and DSS for both olive cultivars (Table 3), similar to what was observed by Streck et al. (2013) in different rice genotypes.

There is a tendency of increase in DSS, except for TT2 and TT5 for Arbequina and TT2 and TT3 for MGSASC315, intensified toward PR3, especially in RCP 8.5 in both cultivars. More specifically, TT7 and TT8 of the Arbequina cultivar presented higher DSS in the three radiative forcing and in the three periods, around 86 days $( \pm 0.311)$ for PR1 and RCP 2.6 and 97 days $( \pm 0.919)$ for PR3 in RCP 8.5. Conversely, TT3 and TT4 will have the lowest DSS in radiative forcing in the short and medium term (PR1 and $\mathrm{PR} 2$, respectively). In addition, long-term TT1 and TT2 (PR3), especially in RCP 8.5, simulated in May and June, will cause a reduction in DSS. In the cultivar MGS ASC 315 in TT2 there was also a reduction of DSS (around 47 days) in the three RCPs throughout the projections. From TT5 to TT9, especially those simulated in September (TT5), October (TT6) and November (TT7), presented an increase in DSS throughout the projections. For both olive cultivars, the VD through DSS was shortened or elongated depending on the simulated transplanting date, like that observed by Streck et al. (2006) with potato cv. Asterix, Streck et al. (2012) with corn, Liu \& Tao (2013) with wheat, and Streck et al. (2013) with different rice genotypes.

Late growing seasons in autumn and early winter will increase VD and reduce DSS; and those cultivated in spring and summer will delay VD and increase DSS. This is mainly due to the fact that $\mathrm{Tm}$ is higher than the Tot of the cultivars equal to $14.7^{\circ} \mathrm{C}$ for MGSASC 315 and $16.1^{\circ} \mathrm{C}$ for Arbequina (Lisboa et al., 2012) and close to a cardinal temperature (TB) of $37.8^{\circ} \mathrm{C}$ (Denney et al., 1985). The development rate increased when $\mathrm{Tm}$ was between $\mathrm{Tb}$ and Tot but decreased when it moved away from Tot and approached TB (Streck et al., 2006; Ruelland \& Zachowski, 2010; Martins et al., 2014). This occurs because in olive crops, Rubisco is the sole enzyme controlling photosynthesis in the metabolic process (Taiz et al., 2018). In conditions with high Tm, the Warburg effect occurs and $\mathrm{O}_{2}$ inhibits $\mathrm{CO}_{2}$ fixation by Rubisco, thereby reducing photosynthesis, increasing photorespiration (Marenco \& Lopes, 2009) and DSS. In practice, it is necessary to reduce the negative impact of increasing Tm in warmer seasons in nurseries where olive seedlings are cultivated. For this, two options can be used namely: shading screens and sprinkler irrigation (Costa \& Streck, 2018).

Considering climate change projections, studies by GarcíaMozo et al. (2010), Tanasijevic et al. (2014) and Moriondo

Table 3. Comparison of means for the duration of seedling phase (DSS, days) for both olive cultivars (Arbequina and MGS ASC315) considering three radiative forcing (RCP 2.6, RCP 4.5 and RCP 8.5) and three projections $($ PR1 = 2011-2040, PR2 = 2041-2070, PR3 = 2071-2100) in Maria da Fé, MG, Brazil

\begin{tabular}{|c|c|c|c|c|c|c|c|c|c|}
\hline \multirow{2}{*}{$\begin{array}{c}\text { Transplanting } \\
\text { date }\end{array}$} & \multicolumn{3}{|c|}{ RCP 2.6} & \multicolumn{3}{|c|}{ RCP 4.5} & \multicolumn{3}{|c|}{ RCP 8.5} \\
\hline & PR1 & PR2 & PR3 & PR1 & PR2 & PR3 & PR1 & PR2 & PR3 \\
\hline \multicolumn{10}{|c|}{ Arbequina } \\
\hline TT1 & $84.8 \mathrm{Cb} 3$ & 81.6 Dc2 & 79.9 Bc1 & $83.1 \mathrm{Ca} 3$ & $79.3 \mathrm{Bb} 2$ & 76.8 Ab1 & $84.1 \mathrm{Db} 3$ & 78.1 Aa2 & 74.8 Aa1 \\
\hline TT2 & $81.6 \mathrm{Ba} 2$ & 79.9 Cb1 & $78.9 \mathrm{Bb} 1$ & 81.3 Ba3 & 78.3 Ba2 & 76.3 Aa1 & 81.1 Ba3 & 77.2 Aa2 & 75.7 Aa1 \\
\hline TT3 & 77.6 Aa1 & 76.9 Aa1 & 76.9 Aa1 & 76.8 Aa1 & 76.3 Aa1 & 76.1 Aa1 & $77.5 \mathrm{Aa} 1$ & $77.5 \mathrm{Aa} 1$ & $80.0 \mathrm{Bb} 2$ \\
\hline TT4 & 78.1 Aa1 & $78.9 \mathrm{Ba} 1$ & $79.0 \mathrm{Ba} 1$ & 77.2 Aa1 & 78.5 Ba2 & 79.9 Ва3 & 78.3 Aa1 & $81.8 \mathrm{Bb} 2$ & 87.2 Cb3 \\
\hline TT5 & $82.1 \mathrm{Bb} 1$ & 83.6 Ea2 & $83.5 \mathrm{Ca} 2$ & $81.0 \mathrm{Ba} 1$ & $83.5 \mathrm{Ca} 2$ & $85.4 \mathrm{Cb} 3$ & $82.5 \mathrm{Cb} 1$ & $87.5 \mathrm{Cb} 2$ & 94.2 Dc3 \\
\hline TT6 & 84.0 Cb1 & $85.5 \mathrm{Fa} 2$ & 85.5 Da2 & $82.9 \mathrm{Ca} 1$ & 85.7 Da2 & 87.6 Db3 & 84.6 Db1 & 89.3 Db2 & $96.7 \mathrm{Ec} 3$ \\
\hline TT7 & 85.4 Da1 & $87.0 \mathrm{Ga} 2$ & 87.1 Ea2 & 84.7 Ea1 & 87.6 Еa2 & 89.0 Eb3 & 86.4 Eb1 & 91.2 Eb2 & $98.2 \mathrm{Ec} 3$ \\
\hline TT8 & 85.8 Da1 & $87.1 \mathrm{Ga} 2$ & $87.4 \mathrm{Ea} 2$ & 85.5 Ea1 & 87.9 Ea2 & 89.2 Eb3 & $86.5 \mathrm{Ea1}$ & $90.9 \mathrm{~Eb} 2$ & $96.9 \mathrm{Fc} 3$ \\
\hline TT9 & 84.2 Ca1 & $85.4 \mathrm{Fa} 1$ & $85.4 \mathrm{Da} 2$ & 83.8 Da1 & 85.7 Da2 & 87.3 Db3 & 84.6 Da1 & $88.4 \mathrm{Db} 2$ & 93.6 Dc3 \\
\hline \multicolumn{10}{|c|}{ MGS ASC315 } \\
\hline TT1 & 137.4 Ea3 & $129.4 \mathrm{Dc} 2$ & 124.1 Cc1 & 134.6 Da3 & $123.8 \mathrm{Bb} 2$ & 114.4 Ab1 & 136.1 Da3 & $116.8 \mathrm{Aa} 2$ & 105.1 Aa1 \\
\hline TT2 & 131.0 Da3 & 127.3 Dc2 & 123.3 Cb1 & $130.4 \mathrm{Ca} 3$ & $123.6 \mathrm{Bb} 2$ & $117.6 \mathrm{Ba} 1$ & $129.7 \mathrm{Ca} 3$ & $118.9 \mathrm{Aa} 2$ & $115.1 \mathrm{Ba} 1$ \\
\hline TT3 & 118.0 Aa1 & $117.8 \mathrm{Aa} 1$ & 118.0 Aa1 & 118.4 Aa1 & 118.9 Aa1 & $118.0 \mathrm{Ba} 1$ & 119.2 Aa1 & 119.7 Aa1 & $127.8 \mathrm{Cb} 2$ \\
\hline TT4 & 118.4 Aa1 & 120.9 Ba1 & 121.0 Ba1 & 118.3 Aa1 & $122.1 \mathrm{Ba} 2$ & $126.5 \mathrm{Cb} 3$ & 119.2 Aa1 & 129.1 Bb2 & $143.9 \mathrm{Ec} 3$ \\
\hline TT5 & 129.2 Ca1 & 132.9 Ea2 & 133.2 Ea2 & 128.7 Ca1 & $135.5 \mathrm{Da} 2$ & 139.4 Eb3 & 130.7 Ca1 & 142.1 Db2 & $156.1 \mathrm{Gc} 3$ \\
\hline TT6 & 132.5 Da1 & 135.5 Ea2 & 135.8 Ea2 & $132.9 \mathrm{Da} 1$ & 138.5 Db2 & 141.8 Eb3 & 133.9 Da1 & 143.5 Dc2 & $155.6 \mathrm{Gc} 3$ \\
\hline TT7 & 132.2 Da1 & 134.9 Ea2 & $135.0 \mathrm{Ea} 2$ & 132.6 Da1 & 137.2 Da2 & 140.4 Eb3 & 133.5 Da1 & 141.5 Db2 & 152.2 Fc3 \\
\hline TT8 & 127.6 Ca1 & 129.8 Da1 & 129.9 Da1 & 127.8 Ca1 & $131.5 \mathrm{Ca} 2$ & 134.0 Db2 & 128.2 Ca1 & $134.4 \mathrm{Cb} 2$ & $143.0 \mathrm{Ec} 3$ \\
\hline TT9 & $121.9 \mathrm{Ba} 1$ & 123.8 Ca1 & 123.9 Ca1 & 122.2 Ba1 & 125.3 Ba2 & $127.0 \mathrm{Cb} 2$ & 122.6 Ba1 & 127.5 Bb2 & 134.8 Dc3 \\
\hline
\end{tabular}

TT - Transplanting date. For transplating dates consult Table 1. Means followed by the same capital letter in the column (radiative forcing), and lowercase letter in the line (transplanting date) and number (projection), do not differ among themselves by the Scott-Knott test at 0.05 probability. Original data is presented in the table above. However, transformation [Ln (DSS)] was necessary, due to the non-presupposition of normality 
et al. (2015) demonstrated changes in the vegetative and reproductive development of olive crops in different regions of Europe. It has been verified that high temperatures $\left(>30^{\circ} \mathrm{C}\right)$ at the beginning of flowering cause floral abortion (García-Mozo et al., 2010; Tanasijevic et al., 2014), while during pollination and flowering affects stigma receptivity, ovule longevity and pollen tube growth, impairing fertilization and fruit formation (Garcia et al., 2018). Concurrently, the duration of flowering and fruiting is shortened (Tanasijevic et al., 2014), indicating that olive crops are vulnerable to climatic changes. In addition, the increase in temperature will reduce the accumulation of chilling hours, which is required by the olive tree to interrupt dormancy, start differentiation of flower buds and have normal flowering (Santos et al., 2017a; Garcia et al., 2018). The insufficiency of chilling accumulation causes a series of physiological anomalies, generating irregularities in sprouting and flowering, which adversely affect the development (Santos et al., 2017a) of the olive tree.

Thus, both the vegetative development, represented by the DSS, and the reproductive development of the olive tree are vulnerable to the projected climatic changes throughout the $21^{\text {st }}$ century. This corroborates the results presented by Santos et al. (2017b) for climatic zoning in MG, Brazil. Such information will affect the choice of the best dates for transplanting and the techniques for seedling production, development of the seedlings in projections of climatic changes, affecting the olive tree management and the success of seedlings establishment in the field.

\section{Conclusions}

1. The increase in air temperature, reaching $3^{\circ} \mathrm{C}$ at the end of the century, will probably modify the development rate and duration of the seedling phase in the cultivars Arbequina and MGSASC315 cultivated in Maria da Fé, MG, Brazil.

2. In colder months, there is increased vegetative development in olive crops and reduced seedling phase duration. Conversely, in warmer months, there is delayed development and longer seedling phase duration.

\section{ACKNOWLEDGEMENTS}

The authors wish to acknowledge the Fundação de Amparo à Pesquisa do Estado de Minas Gerais (FAPEMIG) for financially supporting the projects APQ-01392-13 and APQ 01258-17, and Coordenação de Aperfeiçoamento de Pessoal de Nível Superior (CAPES, process numbers 1827878 and $1489491)$ for granting scholarships to the $1^{\text {st }}$ and $3^{\text {rd }}$ authors.

\section{Literature Cited}

Costa, D. B. da; Streck, N. A. Duração da fase de mudas em eucalipto simulada em cenários de aumento de temperatura. Ciência Florestal, v.28, p.1263-1270, 2018. http://dx.doi. org/10.5902/1980509833378

Denney, J. O.; McEachern, G. R.; Griffiths, J. F. Modeling the thermal adaptability of the olive (Olea europaea L.) in Texas. Agricultural and Forest Meteorology, v.35, p.309-327, 1985. https://doi. org/10.1016/0168-1923(85)90092-9
Fagundes, J. D.; Paula, G. M. de; Lago, I.; Streck, N. A.; Bisognin, D. A. Aquecimento global: Efeitos no crescimento, no desenvolvimento e na produtividade da batata. Ciência Rural, v.40, p.1464-1472, 2010. http://dx.doi.org/10.1590/S010384782010005000091

Ferreira, D. F. Sisvar: A computer statistical analysis system. Ciência e Agrotecnologia, v.35, p.1039-1042, 2011. http://dx.doi. org/10.1590/S1413-70542011000600001

Freitas, C. H. de; Martins, F. B.; Abreu, M. C. Cardinal temperatures for the leaf development of Corymbia citriodora and Eucalyptus urophylla seedlings. Pesquisa Agropecuária Brasileira, v.52, p.283-292, 2017. http://dx.doi.org/10.1590/s0100204x2017000500001

Garcia, S. R.; Santos, D. F. dos; Martins, F. B.; Torres, R. R. Aspectos climatológicos associados ao cultivo da oliveira (Olea europaea L.) em Minas Gerais. Revista Brasileira de Climatologia, v.22, p.188-209, 2018. http://dx.doi.org/10.5380/abclima.v22i0.56825

García-Mozo, H.; Mestre, A.; Galán, C. Phenological trends in Southern Spain: A response to climate change. Agricultural and Forest Meteorology, v.150, p.575-580, 2010. https://doi. org/10.1016/j.agrformet.2010.01.023

IPCC - Intergovernmental Panel on Climate Change. Summary for policymakers. In: Stocker, T. F.; Qin, D.; Plattner, G.-K.; Tignor, M.; Allen, S. K.; Boschung, J.; Nauels, A.; Xia, Y.; Bex, V.; Midgley, P. M. (eds.). Climate change 2013: The physical science basis. Contribution of Working Group I to the Fifth Assessment Report of the Intergovernmental Panel on Climate Change. Cambridge: Cambridge University, 2013. 33p.

Lenderink, G.; Buishand, A.; Deusen, W. van. Estimates of future discharges of the river Rhine using two scenario methodologies: Direct versus delta approach. Hydrology \& Earth System Sciences, v.11, p.1145-1159, 2007. https://doi.org/10.5194/ hess-11-1145-2007

Lisboa, P. M. M.; Martins, F. B.; Alvarenga, M. I. N.; Vieira Neto, J.; Reis, D. F. da. Desenvolvimento vegetativo de duas cultivares de oliveira na fase de muda. Ciência Rural, v.42, p.1556-1562, 2012. http://dx.doi.org/10.1590/S0103-84782012000900007

Liu, Y.; Tao, F. Probabilistic change of wheat productivity and water use in China for global mean temperature change of $1^{\circ}, 2^{\circ}$ and $3{ }^{\circ} \mathrm{C}$. Journal of Applied Meteorology and Climatology, v.52, p.114-129, 2013. https://doi.org/10.1175/JAMC-D-12-039.1

Marenco, R. A.; Lopes, N. F. Fisiologia vegetal: Fotossíntese, respiração, relações hídricas e nutrição mineral. 3.ed. Viçosa: Editora UFV, 2009. 486p.

Martins, F. B.; Pereira, R. A. de A.; Pinheiro, M. V. M.; Abreu, M. C. Desenvolvimento foliar em duas cultivares de oliveira estimado por duas categorias de modelos. Revista Brasileira de Meteorologia, v.29, p.505-514, 2014. http://dx.doi.org/10.1590/ S0103-84782012001100011.

Martins, F. B.; Reis, D. F.; Pinheiro, M. V. M. Temperatura base e filocrono em duas cultivares de oliveira. Ciência Rural, v.42, p.1975-1981, 2012. https://doi.org/10.1590/S010384782012001100011

Moriondo, M.; Ferrise, R.; Trombi, G.; Brilli, L.; Dibari, C.; Bindi, M. Modelling olive trees and grapevines in a changing climate. Environmental Modelling \& Software, v.72, p.387-401, 2015. https://doi.org/10.1016/j.envsoft.2014.12.016 
Moss, R. H.; Edmonds, J. A.; Hibbard, K. A.; Manning, M. R.; Rose, S. K.; Vurren, D. P. van; Carter, T. R.; Emori, S.; Kainuma, M.; Kram, T.; Meehl, G. A.; Mitchell, J. F. B.; Nakicenovic, N.; Riahi, K.; Smith, S. J.; Stouffer, R. J.; Thomson, A. M.; Weyant, J. P.; Wilbanks, T. J. The next generation of scenarios for climate change research and assessment. Nature, v.463, p.747-756, 2010. https://doi.org/10.1038/nature08823

Riahi, K.; Rao, S.; Krey, V.; Cho, C.; Chirkov, V.; Fischer, G.; Kindermann, G.; Nakicenovic, N.; Rafaj, P. RCP 8.5: A scenario of comparatively high greenhouse gas emissions. Climatic Change, v.109, p.33-57, 2011. https://doi.org/10.1007/s10584-011-0149-y

Ruelland, E.; Zachowski, A. How plants sense temperature. Environmental and Experimental Botany, v.69, p.225-232, 2010. https://doi.org/10.1016/j.envexpbot.2010.05.011

Santos, D. F. dos; Leite, R. R. M.; Martins, F. B. Avaliação de métodos de estimativa de números de horas frio para o sul e sudoeste do Paraná. Revista Brasileira de Climatologia, v.21, p.401-416, 2017 a. http://dx.doi.org/10.5380/abclima.v21i0.52382

Santos, D. F. dos; Martins, F. B.; Torres, R. R. Impacts of climate projections on water balance and implications on olive crop in Minas Gerais. Revista Brasileira de Engenharia Agrícola e Ambiental, v.21, p.77-82, 2017b. http://dx.doi.org/10.1590/18071929/agriambi.v21n2p77-82

Souza, P. M. B. de; Martins, F. B. Estimativa da temperatura basal inferior para as cultivares de oliveira Grappolo e Maria da Fé. Revista Brasileira de Meteorologia, v.29, p.307-313, 2014. http://dx.doi.org/10.1590/S0102-77862014000200013

Streck, N. A.; Lago, I.; Alberto, C. M.; Bisognin, D. A. Simulação do desenvolvimento de batata cultivar asterix em cinco cenários de mudança climática em Santa Maria, RS. Bragantia, v.65, p.693702, 2006. http://dx.doi.org/10.1590/S0006-87052006000400021

Streck, N. A.; Lago, I.; Oliveira, F. B.; Heldwein, A. B.; Avila, L. A. de; Bosco, L. C. Modeling the development of cultivated rice and weedy red rice. Transactions of the American Society of Agricultural and Biological Engineers, v.54, p.371-384, 2011. http://dx.doi.org/10.13031/2013.36234
Streck, N. A.; Silva, S. D. da; Langner, J. A. Assessing the response of maize phenology under elevated temperature scenarios. Revista Brasileira de Meteorologia, v.27, p.1-12, 2012. http://dx.doi. org/10.1590/S0102-77862012000100001

Streck, N. A.; Uhlmann, L. O.; Gabriel, L. F. Leaf development of cultivated rice and weedy red rice under elevated temperature scenarios. Revista Brasileira de Engenharia Agrícola e Ambiental, v.17, p.190-199, 2013. http://dx.doi.org/10.1590/S141543662013000200010

Taiz, L; Zeiger, E.; Møller, I. M.; Murphy, A. Plant physiology and development. 6.ed. Oxford: Oxford University Press, 2018. $513 \mathrm{p}$.

Tanasijevic, L.; Todorovic, M.; Pereira, L. S.; Pizzigalli, C.; Lionello, P. Impacts of climate change on olive crop evapotranspiration and irrigation requirements in the Mediterranean region. Agricultural Water Management, v.144, p.54-68, 2014. https:// doi.org/10.1016/j.agwat.2014.05.019

Vuuren, D. P. van; Edmonds, J.; Kainuma, M.; Riahi, K.; Thomson, A.; Hibbard, K.; Hurtt, G. C.; Kram, T.; Krey, V.; Lamarque, J. F.; Masui, T.; Meinshausen, M.; Nakicenovic, N.; Smith, S. J.; Rose, S. K. The representative concentration pathways: An overview. Climatic Change, v.109, p.5-31, 2011. https://doi.org/10.1007/ s10584-011-0148-Z

Walter, L. C.; Streck, N. A.; Rosa, H. T.; Ferraz, S. E. T.; Cera, J. C. Mudanças climáticas e seus efeitos no rendimento de arroz irrigado no Rio Grande do Sul. Pesquisa Agropecuária Brasileira, v.49, p.915-924, 2014. http://dx.doi.org/10.1590/S0100204X2014001200001

Wrege, M. S.; Coutinho, E. F.; Pantano, A. P.; Jorge, R. O. Distribuição potencial de oliveiras no Brasil e no mundo. Revista Brasileira de Fruticultura, v.37, p.656-666, 2015. http://dx.doi. org/10.1590/0100-2945-174/14. 